\author{
Sándor Karikó (Hungary)
}

\title{
Conformist Mass Society or Non-Conformist Rebellion? What education can do to resolve the conformity - non-conformity dichotomy?
}

Must you Conform?

R.M. Lindner

\begin{abstract}
The "profane" meaning of conformism is first provided by American philosopher and liberal thinker William Penn, in his work dated from around 1700. According to Penn, conformity is a civil virtue whose price is the loss offreedom. The description of conformity as deprivation of freedom becomes stronger in $20^{\text {th }}$ century philosophy from Heidegger through Fromm up to Fischer's definition as "the sinking of the Self into the Anyone is conformism." Education and pedagogy have serious debts as to the recognition of and solutions to the problem of conformity. In the community relations of the students, the principle of the structural regularity of increasing conformity, and in our schools, the easily adapting and more so conforming student have become the ideal. And where is the place, the value of conformity and nonconformity in society? And first of all: what can education do against the deceptive contrast of conformity - non-conformity. That is a matter ofgreat importance.
\end{abstract}

Keywords: conformity, non-conformity, community, autonomy, education

摘要 (Sándor Karikó: 顺从性的大众社会还是非顺从的反般? 教育可以做些什么来解决这一二分法: 顺从性与非顺从性）：顺从性的“琶渎”含义最早是由美国哲学家和自由派思想家威廉·佩恩（William Penn）在他 1700 年创作的作品中提出的。佩恩认为顺从是一种公民的美德，其代价是自由的丢失。 在20 世纪的哲学中，从海德格尔到弗洛姆，再到费舍尔的“将自我沉入每一个个体即是顺从”的定义， 对顺从的描述是对自由的剥夺 -.- 这一说法变得愈发强烈。教育学在承认和解决顺从性问题方面负有 重大责任。在学生的社区笑系中, 不断增加的顺从性的结构规律性原则以及在我们学校中易于适应且 更加顺从的学生已成为理想之选。那么, 在社会中顺从与非顺从的地位和价值在哪里? 首先 : 教育 能够对顺从与非顺从之间的欺骗性对比做些什么? 这是一个非常重要的问题。

关键词：顺从，非顺从，社区，自治，教育

\begin{abstract}
摘要 (Sándor Karikó: 順從性的大眾社會還是非順從的反般? 教育可以做些什麼來解決這一二分法： 順從性與非順從性）：順從性的“聟瀆”含義最早是由美國哲學家和自由派思想家威廉·佩恩（William Penn）在他 1700 年創作的作品中提出的。佩恩認為順從是一種公民的美德，其代價是自由的丟失。 在 20 世紀的哲學中，從海德格爾到弗洛姆，再到費舍爾的“將自我沉入每一個個體即是順從”的定義， 對順從的描述是對自由的剝奪--- 這一說法變得愈發強烈。教育學在承認和解決順從性問題方面負有 重大責任。在學生的社區關係中，不斷增加的順從性的結構規律性原則以及在我們學校中易於適應且 更加順從的學生已成為理想之選。那麼, 在社會中順從與非順從的地位和價值在哪裡? 首先 : 教育能 夠對順從與非順從之間的欺騙性對比做些什麼? 這是一個非常重要的問題。關鍵詞：順從，非順從， 社區，自治，教育
\end{abstract}

Zusammenfassung (Sándor Karikó: Konformistische Massengesellschaft oder nicht-konformistische Rebellion? Was die Bildung tun kann, um die Dichotomie Konformität - Nicht-Konformität aufzulösen): Die "profane" Bedeutung des Konformismus wird erstmals vom amerikanischen Philosophen und liberalen 
Denker William Penn in seinem um 1700 entstandenen Werk dargelegt. Penn zufolge ist Konformismus eine bürgerliche Tugend, deren Preis der Verlust der Freiheit ist. Die Beschreibung der Konformität als Freiheitsentzug wird in der Philosophie des 20. Jahrhunderts von Heidegger über Fromm bis hin zu Fischers Definition als "das Versinken des Selbst in den Jedermann ist Konformismus" stärker. Erziehung und Pädagogik haben große Schulden, was die Anerkennung und Lösung des Problems der Konformität betrifft. In den Gemeinschaftsbeziehungen der Schülerinnen und Schüler ist das Prinzip der strukturellen Regelmäßigkeit der zunehmenden Konformität und in unseren Schulen der leicht anpassungsfähige und mehr noch konforme Schüler zum Ideal geworden. Und wo ist der Platz, der Wert von Konformität und Nonkonformität in der Gesellschaft? Und vor allem: Was kann Bildung gegen den trügerischen Gegensatz von Konformität - Nonkonformität - tun? Das ist eine Frage von großer Bedeutung.

Schlüsselwörter: Konformität, Non-Konformität, Gemeinschaft, Autonomie, Bildung

Резюме (Сандор Карико: конформистское массовое общество или нонконформистский бунт? Чем может помочь образование при выявлении специфики дихотомии «конформизм нонкорформизм»?): Классическое определение конформизмубыло изначально дано американским философом и либеральным мыслителем Уильямом Пенном в его труде, увидевшем свет ориентировочно в 1700 году. Согласно этому определению конформизм - это мещанская благодетель, за которую установлена конкретная цена - утрата свободы. Описание конформизма как утраты свободы становится популярным в философии двадцатого века - это прослеживается от Хайдеггера и Фромма до Фишера. По Фишеру конформизм - «это подчинение себя другому или другим». Воспитание и педагогика имеют неоплаченный долг в том плане, что до сих пор до конца не осознана и не решена проблема конформизма. В коллективных отношениях между учениками идеальным вариантом становится принцип структурной регулярности возрастающего конформизма, а идеальным поведением учеников - умение легко подстраиваться и приспосабливаться, комформность. В связи с этим возникает вопрос: а где место и какова ценность данной дихотомии? И самое главное: что может сделать образование для разрешения этого ложного противоречия (конформизм - нонконформизм). Это вопрос, имеющий большое значение.

Ключевые слова: конформизм, нонконформизм, коллектив, автономия, образование

\section{Adaptation or conformity?}

If Castoriadis's statement that we live in the most conformist period of modern history (Castoriadis, 1994, p. 48) is true and, furthermore, one accepts the criticism of Miklós Tamás Gáspár that today's Hungarian society is a 'chameleon-like' order which adapts to societal changes and does not set any kind of moral requirement for citizens: they do not have to be 'good', generous (Gáspár, 2020, p. 5), one can rightfully expect that one has a considerably rich and sure knowledge of conformity. With the accumulation of different types of knowledge in a large quantity, its interdisciplinary adaptation should not pose any issues. Nevertheless, one might also have the impression that along with the various intellectual endeavours (first and foremost sociological, social-psychological and politological works), the philosophical and artistic (art-historical) approaches have been marginalised, which is really lamentable and incomprehensible to me. What is more, the science of pedagogy has so far only been able to present a considerably limited amount of results on this theme. The major problem in fact is that conformity research has not been able to provide us with a satisfactory, straightforward and unified interpretation: there are too many misconceptions, statements not profoundly proven and even misbeliefs and stereotypes. The popular and spectacular but mostly superficial views only aggravate the uncertainty. Let me highlight three of the problems to be clarified:

1. Can researchers from different kinds of disciplines agree on a common conceptual basis of conformity? Can it at all be expected to come up with a unified meaning of conformity accepted by everybody? 
2. What should be done with the emerging propagation of non-conformity? Primarily, what is the relation of non-conformity to conformity?

3. Where and when does the pedagogical aspect of these problems of conformity and non-conformity emerge? Last but not least, do we want to take steps against conformity and non-conformity with the help of education?

Although it is obvious that there are many questions to be answered, I would like to shortly discuss and summarise the three above-mentioned dilemmas with the proposition of some theoretical morals I consider important. As will become evident, I could condense the whole of my investigation into one single question: Is conformity identical to adaptation in itself? Let me indicate my answer in advance, obviously it is not.

\section{"The sinking of the Self in the Anyone"}

The theme of conformity was introduced to social sciences with the theory of the sociologist, Robert Merton in the second half of the $20^{\text {th }}$ century. According to him, conformity is ageneral and instinctive reaction which inherently maintains the stability and continuity of society. In other words, there is a necessary, self-explanatory and "neutral" form of adaptation. In parallel with it, a consciously professed adaptation which does not stem from personal conviction is a negative phenomenon in itself. His concepts merge into one another: he uses adaptation, conformity and over-conformity. (Merton, 1959)

The problem in that case is that various meanings are used, and there is no clear-cut distinction among them. The indication of the borderlines among the different connotations does not take place, which obviously causes uncertainty. The uncertainty has been conveyed through various pieces of research. Its typical example is the book on conformism by the Italian academic, Angelica Mucchi Faina. According to her, it is important to separate conformism in its broad sense which is approaching the behaviour, way of thinking and emotions of others in any manner from its narrow sense which means adapting to a given way of thinking and acting, because it is the dominant one in that particular society or community he problem is to find where the borderline between conformity as a successful integration of individuals into society and futile, servile conformity is (Mucchi-Faina, 1998, p. 8, p. 117). The dual meaning of conformity unravels: on the one hand, the general and necessary conformity in a broad sense, on the other, the futile, harmful and servile one in a narrow sense. According to the Italian psychologist, public awareness does not usually distinguish between the two interpretations and primarily uses the second, pejorative sense. Seizing the exact borderline between them is however missing, and, lastly, researchers in that discipline have not been able to carry out this task. They only realise that two meanings emerge.

Sociology and social psychology have come up with several propositions in relation to the discrepancy between these two connotations. For example, Wiswede debates positive and negative conformity: Conformist behaviour triggers negative associations in some cases, in others positive ones. Anybody not pestering others and meeting social expectations is labelled a conformist in a positive sense it is of negative nature in a sense that one adjusts the best of one's beliefs and knowledge to that of the others (Wiswede, 1976, pp. 11-12, p. 96). The researcher, Peuckert makes a distinction between supple conformity (in German: Anpassungskonformität) and attitude conformity (Attitüde-Konformität) (Peuckert, 1975, pp. 11, 125). The latter will be the natural, inherent adaptation without value judgement. Lastly, let me refer to the proposal of the Hungarian sociologist, András Hegedús. One should separate the conceptions of conformity in a manner that one uses conformity in its inevitable sense without value judgement from conformity in a way that means adapting to the norms of its supposed or actual superiors without using critical reflection (Hegedüs, 1981, p. 177). 
Without going into further details concerning social-psychological experiments (others have already done it), it is obvious that a new viewpoint has been implemented into conformity research. The phenomenon has been linked to group influence and pressure: the opinion of individuals is different before (or without) the group pressure than that of after (or with) it. After certain antecedents (the "autokinetic" examination of Muzafer Sherif), Solomon Asch with the help of his famous line judgement experiment pointed out that healthy, grown individuals are also willing to profess opinions which are in opposition to facts, their own experiences or all of them (Asch, 1951, p. 70) The main merit of social-psychological experiments is that they deny the psychological myth according to which humans are egocentric, arbitrary and irrational beings. Conversely, in the case of society functioning, there are inevitably rational uniformities. Despite that, the necessary prudence and critical thinking are not unjustified. Furthermore, one must also realise that the "Asch studies of conformity may not be universal (...) the Asch effect should not be assumed to be normative" (PerrinSpencer, 1981, p. 20). To put it differently, one cannot be sure that conformity is based on general human propensity and can hardly consider it to be a characteristic feature. A further problem is that attempts to distinguish between these concepts have also been made, for instance in the case of sociology. Here, Ackerman urges that "one must separate emotionally healthy conformity from the superficial and defensive type of conformism which does not serve the interest of the actual integration of individuals" (Ackerman, 1969, p. 334).

The ambiguity and uncertainty originating from these problems also surface in the related Hungarian social psychology. György Csepeli uses the following definition: What is called conformity is basically the expression of the need for group members. (Csepeli, 1979, p. 93) However, Tamás Oláh firmly claims that conformism means cringing behaviour in everyday life it is used in the same sense in social psychology (Oláh, 1978, p. 22, p. 51).

On the basis of the sociological and social-psychology overview presented up till now, an important conclusion can already be drawn. It is not necessary to condense different meanings into the usage of one single concept. The clairvoyance is hindered by the fact that the root-word conveys two fundamentally contrasting connotations: on the one hand, a general inevitable one without any value judgement from a moral point of view which means an adaptation to the norms and laws of the given society, and, on the other hand, a less universal and actually negative, harmful, cringing and servile conformity. The former one is an inexorable condition of the normal functioning of society, and, at the same time, a function of the survival and welfare of each individual no matter what their individual goal is. The latter one is a distorted form of adaptation meaning a servile behaviour which individuals can, of course, admit consciously but can also deny. Generally, one accepts the former one as the objective law of cohabitation and functioning, and condemns the latter one. Nevertheless, these two meanings are interchangeably and arbitrarily used without any valid reason. Arguably either the interchangeability or arbitrary utilisation are inadequate. It is time to get rid of associating several connotations with one single concept.

It is obvious to me that differentiated interpretation and usage of concepts is not only a desirable but necessary procedure. It is important for researchers to agree upon an unequivocal and universal semantic content of conformity and stick to it consistently. The original meaning of the concept which can be considered as its classical sociological and philosophical sense could help us establish its new common meaning.

Its etymological meaning originates from the Latin 'conformare' (to adapt). In fact, the interpretation widespread in public awareness and sometimes disciplines that the phenomenon is nothing else but the sheer adaptation to something and/or somebody also stems from this origin. As one has already seen it, such a sense can only lead to simplification and superficial knowledge causing turmo il. So, as such, it does facilitate its clarification. 
It is also known that conformism has a religious meaning, as well. According to this, a conformist in England was a person loyal to the Anglican Church, and, in contrast, someone who did not accept the teachings of the established church was called a non-conformist. An interesting religious historical correlation could unfold at that point, nevertheless, in the following I would like to focus on its secular meaning.

Its secular and philosophical understanding - as far as I know - was first established by the American liberal thinker, William Penn, at the beginning of the $18^{\text {th }}$ century. In his book written around 1700 (it does not have an exact publication date), he defined the concept in the following manner: conformity is such a virtue for which the price is the loss of liberty (Penn, 1971, np). Another American philosopher, Emerson, interprets it in a similar manner. In his famous essay, he emphasizes that "[s]ociety is a joint-stock company, in which the members agree, for the better securing of his bread to each shareholder, to surrender the liberty and culture of the eater. The virtue in most request is conformity." (Emerson, 1988, pp. 2-3). Here I would like to note that I make an important distinction between conformity and conformism: the former one refers to the process of the phenomenon, the latter to the very existence of the trend. Later on, in history, Nietzsche laments that the modern era is becoming subjectless, uniqueness is gradually disappearing, "compulsory external uniformity [is reigning] [...] modern man suffers from a weakened personality [...] Instead he masks himself as an educated man, a scholar, a poet, a politician" (Nietzsche, 1989, p. 97). Heidegger further elaborates on the description, in possibly the most suggestive part of his most influential work:

In this way, the 'they' disburdens Dasein in its everydayness. Not only that; but disburdening it of its being, the 'they' accommodates Dasein in its tendency to take things easily and make them easy [...] Everyone is the other, and no one is himself. The 'they', which supplies the answer to the who of everyday Dasein, is the nobody to whom every Dasein has always already surrendered its itself, in its being-among-one-another (Heidegger, 2010, p. 124).

From many conformity researchers having reflected on the above-mentioned ideas of Heidegger, let me highlight the ideas of two of them. The less known Thomas Barfuss interprets the ideas of the authors of Being and Time in his book on conformity:

Mr. Dasein and Mrs Dasein were unable to find the escape route from conformity" (Barfuss, 2002, p. 217). Ernst Fischer comes up with the briefest definition grasping the deepest layer of meaning: 'The sinking of the Self in the Anyone' is conformism (Fischer, 1964, p. 97).

It becomes obvious based on the above-mentioned quotation that social theory and philosophy regard - nearly exclusively - conformity as an unequivocally negative social phenomenon. In accordance with all this, it is a state deprived of freedom in which individuals do not think, decide, feel and act as they would otherwise do. Some researchers unmistakeably summarise the whole range of problems by replying to the fundamental questions: Who is a conformist? What is conformism? A conformist is a person who does not have his own principles and actions. He adapts to any groups in 'chameleon-like' manner. The conformist action is hideously corrupting virtuous life (Peters, 1974, pp. 194-195, p. 251). Ivanov, a Russian sociologist, only strengthens the standpoint of the quoted author. According to him, conformism is the inevitable subordination of the personality to the exterior, officially approved clichés and standards, it is the obedience to 'the social elite' and attention to all those who matter. It is the form of existence of a pared-down personality (Ivanov, 1980, p. 84).

On the basis of social scientific tradition and a part of socio-psychological and sociological investigations (probably a decisive part of it), one can rightfully emphasize that conformity's sole meaning is the distorted and exclusively harmful manifestation of adaptation. The phenomenon of adaptation in a broad sense should strictly be separated from its distorted and noxious manifestation. Adaptation in a broad sense, as seen above, is the rational and natural acceptance of basic social 
norms, principles, rules and laws. The integrity of the self will not disappear because of it. In consequence, it is not at all justified to label adaptation as conformity, what is more, adaptation should not be considered as a given part of conformity either.

Based on the facts mentioned above, I would like to offer the following definition: conformity is a kind of adaptation which comes with the mutilation and many times complete denial of the Self, it is the manifestation of subservience and compromise, by which the individual loses and denies his own conviction, integrity and freedom. Its consequence is that he does not know anymore who he actually is.

In relation to the above-mentioned conception of conformity, let me make two important remarks:

1. In Hungarian public awareness and public life, one usually comes across the overwhelming argument that in Hungary during the period of the regime change (end of the 1980s, beginning of the 1990s) the conformity problem became more accentuated. The phenomenon of a large number of citizens becoming conformists caught one's eye: they changed their point of view, conviction and behaviour without any problem, often several times. As they said and wrote: The Road to Damascus has become crowded (referring to the biblical events when Saul suddenly became Paul). And it seems that the phenomenon of conformity has not disappeared even nowadays. A contemporary publication claims that even today 'Being servile' reigns. (...) Nodding and curtseying, (...) hey Kadar's people, hey! (Dévényi, 2020, par. 8). However, we must look for the roots of the phenomenon of conformity deeper in Hungary. Only one further comment: Sándor Petőfi (he was a Hungarian poet in the $19^{\text {th }} \mathrm{c}$.) made a similar observation in the middle of the $19^{\text {th }}$ century: "Until March 15 entire Hungary was a servile country, a country as humble as a dog" (Petőfi, 1956, p. 97). The start of systematic conformity research would also be justified in the light of similar remarks. I consider it important even if I do not agree with those who utilise the similitude of the Road to Damascus to describe the phenomenon. Becoming Paul - in accordance with the original story - is not an example of opportunism, as he had fundamentally changed, his inner self had been completely transformed, and he had become a new person in all respects. Citizens can go through such a genuine, open, critical and self-critical transformation: every person has the right to go through that. The individual who experiences such an alteration cannot be regarded as a conformist. Nevertheless, the person who alters easily and repeatedly throws out his or her convictions, principles and behaviour patterns with no remorse, can be called conformist.

2. The other addition touches upon a serious philosophical dilemma. If one accepts the interpretation that conformism means opportunistic adaptation and the conformist such a person who frequently and easily changes his or her standpoint and behaviour, because they do not have a firm intrinsic guiding principle (see the following lines of Attila József: "My leader leads inside of me."), then what should one do with Descartes's four-century-old maxim? Namely, that nothing remains in the same state forever (...) I would have made a big mistake (...) against pure reason, because now, if I considered something right at the moment, then I would oblige myself to consider it right later on, when it may not be or when I may not consider it that way (Descartes, 1992, p. 37). The challenge is considerable: What standpoint should one take? Do we condemn conformism and conformist people regarding them as negative and harmful manifestations or stick to Descartes' idea (as things change, one should change, too)? Does one become conformist if one openly admits that one changes regularly? If things alter all the time, and one flexibly adapts to them, then is it a positive behaviour? If yes, how should one accept the rise of the conformist person continuously in adaptation? Then should conformism not be considered negative? In general, what is the link among conformism, altering things and adapting to the environment? These are behemoth and exciting questions which deal with a deep philosophical dilemma into which conformist 
researchers could do independent investigations. I must admit that I cannot answer this question at the moment. Nevertheless, I am sure that human adaptation has such a form in which the individual's integrity and level of freedom are curbed or we do not want to make use of all our abilities, skills and resources. This resignation, this conception (and practice) of human adaptation can be contested from a philosophical, historical viewpoint and condemned from a moral one.

\section{Non-Conformity against Conformity}

As seen above, according to many academics, the phenomenon of conformity is a harmful social development. Many of them tend to think that its positive counterpart is non-conformity. The nonconformist adaptation will be the example to follow. In the public awareness, press and sometimes even literature, its appreciation and a myth according to which it is superior to conformity are strongly present. Practically, the Western students' movements in 1968 closely examined the question of conformity. The students' revolt, which started in nearly 50 countries, shook the life and political mechanisms of societies. The ideal and practice of protesting against the conformist world fascinated the young people. The sociologist, Cooley, set the tone for the theoretical foundations: "[Y]outh glories in nonconformity" (Cooley, 1967, p. 304). Later, the students firmly declared their goal: "breaking with the tradition, conformity, order and formalities: they wanted passion, blood and real life." (Feuer 1969, 35) Adam Michnik, from the new wave left wing thinktank, drew his conclusions from 1968 in the following manner: "You must be non-conformist" (Michnik, 1998, p. 19). If one wants to articulate this in a universal manner: "Whoever wants to be human has to be nonconformist" (Emerson, 1988, p. 20).

Nevertheless, in my humble opinion, such and similar excessive evaluations of non-conformity cannot be accepted, neither in theory nor practice. In terms of the latter, one could experience that, for example, the rebellion of the 68er West German students had transformed back into conformity by the middle of the 1970s. At that time a new philosophy of life was starting to become popular: 'Dear God. Make me spineless, so that I can work in the Civil Service.' One should not be surprised that the majority of student leaders were integrated into the state 'mechanism', into the Civil Administration or into State agencies. It is obvious that one cannot fight against conformism with non-conformism.

Theoretically, it turns out that many researchers question the justification of the establishment of the conformity - non-conformity opposition. First of all, let me refer to the excelling social psychologist, Crutchfield, who wittily pointed out the false dilemma of the dichotomy. According to this researcher, conformity is the unprincipled alignment to the opinion of group mates, and non-conformity is the unprincipled resistance to it (Crutchfield, 1955, pp. 191-198). To put it differently, these two forms of adaptation have a common origin, it is giving up autonomy and depending always on the others. Thus, "conformity is thinking and doing what the others are professing and doing, non-conformity is taking a position which is opposed to that of the others. In both cases, one is led by the opinion of the others, not by one's own conviction. Consequently, non-conformists are actually similar to one another as are conformists. The borderlines between these two forms completely merge into each other, one can easily switch between them. György Lukács, a well-known Hungarian philosopher summarizes that in modern societies non-conformist conformists emerge (Lukács, 1976, pp. 797-798).

It is clear to me these two concepts are relative: one cannot go beyond the boundaries of one of them with the other, as they are not the oppositions of each other. In this context, one must pay attention to the remarks of two social psychologist siblings:

The laymen often think of conformity as a personality trait: there are the conformers and then there are the non-conformers. Whether the layman thinks of himself as a conformer or not 
may depend upon whom he is comparing himself to. If he is considering himself relative to those he considers beatniks, hippies or bums, he is staunch conformer - he is not, in his own eyes, one of those awful non-conformers who are likely to reject mother, God, and Country all at once. However, if he is asked if he believes in 'changes for the better' (whatever they are), he will suddenly assume that he is a brave non-conformer unshackled by inhibitions and fears of the old fogies. While we often are attracted by the idea of conformity as an enduring personality trait, we may be unwilling to accept it in ourselves (Kiesler, \& Kiesler 1969, p. 11).

The authors correctly recognise that these concepts are relative, there is no real opposition between them: the dilemma of conformity and/or non-conformity is a pseudo one. One can only agree that it is not a personality trait.

After all that, the question is: if they do not form real alternatives, then how should a person be divergent from the others? To find an answer, let us turn to the Russian social psychologist, Petrovsky who harshly criticises the results of related American experiments: we must re-evaluate - argues the researcher - the model of group cooperation proposed by the American psychologists. The presented model (such as, Asch, Deutsch, Kraus, Gerald, Perrin and others - S. K.) cannot be regarded as an authentic model of the relationship of people in a given community, as it does not mean anything to those who participate in the experiment. In the given case, the values with which the group could have conflicted were missing, in other words, there would have been no dispute. The real alternative to conformism is social self-determination and not non-conformism (Petrovsky, 1973, pp. 75-76,). The criticism of the author is true obviously from a given point of view - in the sense that artificially constructed 'laboratory' results are completely different from the data based on processes taking place in reality, not to mention the real conflicts of interest and value preferences, especially their role in social processes. On the other side of the coin, it is not really sound to underestimate the importance of empirical research. Even if the criticism of the experimental data is justified, one must not forget the general human characteristic that we desire social acceptance, and it is the basic foundation of normative influence. Conformity is the shortest way to social acc eptance. Humans are guided by two basic desires, one of them is to belong with the others and the other is to be unique (Papyrina, 2012, p. 468, p. 474). To put it in another way, people want to become similar to the others, but they desire to differentiate themselves from the other members of the group.

I agree with the solution proposal made by Petrovsky, namely that the real community offers social self-determination for actually going beyond conformism and non-conformism together as a group. In fact, one can find the solution in terms of (the frequently mentioned and many times discredited) social existence. The questions in that matter are: What is the essence of the real community? When does a group become a community? and How does social existence relate to the two forms of adaptation?

Without going into the details of the rich literature on the topic of community, I must shortly refer to my own interpretation. It is evident for me that the community is neither constructed from above nor artificially created, what is more it is not an organisation that subordinates individuals, as Petrovsky claims. It is not a diffuse group ("podsztávnájá gruppá") but an organic and superior cooperation constructed from its grass roots in which each member of the community has an equally important role as the organisation embracing them has (organisation, institution). If it comes into being, social and individual existence will come together just as the community and individual. Sociability and individuality nurture each other, a unified entity emerges: an individual can only exercise its power through social cooperation, and vice versa the community thrives on the will, fantasy and deeds of its members. If the organic cooperation increases, it will make the development of social existence of quality possible. Let me add the expressive example of Dworkin: an orchestra can play a symphony, but a sole musician cannot. It is not the case of a collective action in a statistical sense, because each member of the orchestra not only has to play a certain part of the musical score, 
but they should play together as an orchestra, each of them must be willing to contribute to the performance of the group, they should not play isolated tones (Dworkin, 1993, p. 3). A symphony played in synchrony and harmony is authentic and becomes a general and remarkable collective experience.

In that sense, what is the role of conformity and non-conformity in a community? One can face some uncertainties in relation to answering the question. Kim, the philosopher of the Lomonosov State University reckons that both forms of adaptation can be found, in addition, one can easily switch from one to the other, so these two phenomena are not mutually exclusive. In general, conformity and nonconformity necessarily exist in social interactions (Kim, 2014, p. 84, p. 94). Others are not so permissive. For example, the Mehlhorn pedagogue siblings warn us that creativity and conformity exclude each other. They state: "Our educational system trains conformists, stereotypical individuals instead of free, creative and authentic thinkers" (Mehlhorn, \& Mehlhorn 2003, p. 25, p. 28). They are certainly right, but I would like to elaborate on the criticism: in a real community (in the abovementioned sense) there is actually no place for either conformists or non-conformists. Both of them as I have already mentioned above - are distorted forms of adaptation, and the community does not consider its members as subordinated servants but autonomous individuals.

The primary duty and responsibility of the disciplines dealing with the topic (especially practical pedagogy based on theoretical pedagogy) is the recognition and promotion of the correlation that the community is able to avoid the false dilemma of conformity and nonconformity. More exactly, it would be desirable to raise the awareness of community formation and its functioning which can banish these extreme forms of adaptation. The real community - emphasized again - is free from all kinds of conformist and non-conformist forms of adaptation. The correct theoretical direction is indicated by Ferenc Lóránd, a Hungarian pedagogy researcher whose results have been disregarded, which is incomprehensible to me. The transformation of our pedagogical culture is both useful and reasonable in a manner to allow the youth to accept the world by denying it and to deny the world by accepting it (emphasis by S. K.). If the denial of reality becomes stronger, the individual will become marginalised. In contrast, if reality is accepted, the individual will give up on his sovereignty and will become conformist (Lóránd, 1999, p. 36, "tlb"). The community can work its "fine" distance out: identifying oneself with the norms of the community does not hinder the headway of the individual, but it extends and enriches it. It is true the other way around: the objections and arguments are not the spectacular manifestations of rebellion, but they are part of the natural cohabitation.

I am aware that it is hard to put the differentiated relation and proportion of acceptance and denial into practice, and it is even harder to make it widespread. However, if one renounces the task, it can result in the survival of the false dilemma of conformity and nonconformity.

The above-mentioned quotes (the ideas of Mehlhorn and Lóránd) indirectly imply the pedagogical aspect, namely the examination of my third objective (the big or even the biggest challenge of education): the aspect of education: the formation of the "Polite"," Rebellious" and "Autonomous" Individual. In fact, one could launch the pedagogical research on conformism and all the related correlations from this starting point. Nevertheless, pedagogy faces a huge challenge: the elaboration on the topic in Hungary has such a fall-back that it would be an illusion to try to come up with a coherent and grandiose examination. It is an old scientific experience that one cannot omit research phases without any negative repercussions. One must simply be satisfied with a modest objective, a small result (for the first attempt). I would like to draw the attention to two theoretical conclusions hoping that it can help the pedagogical research conducted later on find the right direction.

It seems evident to me that the polite person is the conformist, the rebellious one is the nonconformist, and the autonomous individual is the positive example with the help of which or whom one can fight against both conformism and non-conformism. 
I have already mentioned above that the extreme and distorted forms of adaptation cannot be regarded as personality traits. At least in the sense that nobody is born as a conformist or nonconformist. Neither of them is predestined, but both of them are the results of social (economic, political or psychological) processes, otherwise these social processes can make conformism and non-conformism disappear. If it is true, it can be admitted that one can fight to overcome them. Obviously, it does not mean that one should mock or criticise such a behaviour. Neither can one expect much more from its moral condemnation. One should primarily concentrate on how the positive example could be made convincing, meaning how to emphasize the power and importance of social existence (and those of the individuals who are part of it). One can rightfully hypo thesize that the more the autonomy of individuals and institutions develops and solidifies, the more the conformist and non-conformist manifestations lose their significance. One can teach autonomy to individuals, and communities can also be educated to be autonomous. One can of course fight conformism and non-conformism in many ways and with many tools (for instance, in the spheres of politics, economics and the media - that should be the scope of other studies), although the frontlines of education seem to be self-explanatory. This approach has not yet been exploited by theoretical and practical pedagogy. It is not true that these disciplines cannot do anything in that matter, they are still in the very early stages of their work. In fact, one should draw the attention to and sacrifice energy on why and how we should educate people to be autonomous. I think nothing can replace this task, - to articulate it more precisely - this mission.

According to my beliefs, we can and must educate people towards autonomy. This superior task is first and foremost the responsibility of professionals dedicated to education, as other people or organisations do not show the same willingness to do so. If one ignores, simply orally supports or supports the endeavours for autonomy only in official declarations, it will result in society being infantilised. In order to avoid that, people trying to improve the pedagogical culture, especially the leaders of and participants in educational work can do a lot about it. They can do even more than many would think.

It is obvious that pedagogical research has not really or pusillanimously dealt with the correlations of the themes of school-conformity and school-autonomy. It is not a coincidence that the question of school and conformity was not scrutinized first (meaning the last few decades of the last century) by researchers of pedagogy. The representatives of and those who were responsible for pedagogy did not say a word. The psychologist, Péter Popper, a Hungarian psychologist articulated a sharp criticism in the 1970s: in our schools the well-adapting and conforming pupil has become the universal ideal (Popper, 1975, p. 354). László Lengyel, a Hungarian economist, provided further insight into these problems and included higher education in his criticism: at restricted mass universities, in an imitating and colonial system, the mass production of prefabricated and conformist students was taking place (Lengyel, 2001, p. 32,). After these remarks, there was nothing to be found on the subj ect. The conformism problem remained unchanged, but in the last few decades something has happened in the frameworks of pedagogy. It seems that pedagogy is starting to recognise the issue. A selfcritical attitude can be observed in a book published in 2017: a traditional pedagogical practice forcing students to take a passive and receptive position reigns, children must adapt to the school and not the other way around (Radó, 2017, p. 11). Our educational system is in a rather narrow state, and that has serious repercussions. The author continues in his new publication in the following manner: all influential participants have given up their integrity (Radó, 2017, p. 67). Tamás Vekerdy, a Hungarian psychologist, who is blessed with a rather strong pedagogical affinity comments on the unfortunate situation such that the good old Prussian meat grinder is returning: in the front you squeeze the student in, and on the other side, it ejects the standardised subject. (Vekerdy, 2019, p. 8). A particularly neglected area of the pedagogy is the education of disabled children (Kovács, 2014). Last but not least, let me quote the harsh criticism of the pedagogy researcher János Szüdi, who died last year (as one can read in his iconic book entitled Csináljukrossz iskolát! [Let's make a bad school!]: 
in an education system serving the interest of the political power, there is no freedom of education, there are no free schools. The child feels good in school if he feels that what is happening there serves his best interests, if he feels that he has equal rights in the community, he is a respected member of it, and if he feels that he is part and not the passive subject of the learning process (Szüdi, 2019, p. 7).

The above-mentioned critical initiative can be a firm foundation in the battle of pedagogy against conformity. It is obvious to me that one must break with the phenomenon of conformist adaptation if one wants individuals (and their organisations) to think independently and freely about the world and themselves in order to live and function autonomously. If one understands and accepts this correlation, then one is just few steps away from the realisation that the solution is not offered by the non-conformist model but by the establishment of a community in which the endeavour to be autonomous becomes natural. Neither the obedient nor the rebellious youngster should be the ideal but the social and autonomous human being!

On the basis of this short inquiry, I have become convinced that the most effective way to struggle against conformity and non-conformity is to set the endeavour for autonomy as a positive example. One can criticise and condemn these distorted forms of human adaptation, but such an approach will produce less results. Instead, one should rather concentrate on the question of how the autonomy needs of the individuals, organisations and institutions could be facilitated and how our autonomy needs could be served on a high level or at least a higher level than at present. One must rethink many arguments and interests. The proper political willingness and standpoint are not exclusive but, nevertheless, extremely important requirements for such a long-term process. However, I have not dealt with the political (especially politico-educational) and politological aspects of the topic, there is no doubt that sooner or later one must pose the decisive question: To what extent do politics - the whole trend with its various rules, measures and laws - serve the endeavour for autonomy? And vice versa: to what extent does it force young people (and of course everybody else) into servile adaptation? It can hardly be contested: as countries and states do need autonomy (along with different kinds of international cooperation), concrete individuals can rightfully expect society to secure their own autonomy. From that perspective, it is not really reassuring to me that in the new NAT (Hungarian National Curriculum) the definition and objective of autonomy are not present in either its introduction/preamble or in the point called 'Key Competencies and Skills', which further strengthens my presupposition that in terms of educating towards autonomy and independent reflexivity, politics and educational politics have many tasks to fulfil. First and foremost: they must at least set a few goals.

From a pedagogical viewpoint, it is a fundamental criterion that neither conformist nor nonconformist teachers and pedagogues (or even parents and everybody else) should be able to effectively stand up against these extremes of human adaptation. Or is it an inconvenient question to ask what kind of people pedagogues are: conformists or non-conformists? Do they possess the competency to be autonomous and skills of being autonomous? If they belong to the abovementioned categories, one cannot expect them to not educate their pupils in either a conformist way or a non-conformist one. The pedagogue who is neither conformist nor non-conformist can, of course, do so, he or she can become an autonomous personality, a positive example. One of the teachers' most important traits (if not the most important) is authenticity. I hope that for most of us authenticity is a superior moral content, a valuable virtue which means that the ideas, beliefs and communication of that given person are in harmony with his or her deeds, behaviour and whole existence. A person is authentic if his or her thinking and personality materialise in the person in an own unique way. (Karikó, 2005, pp. 47-48). 


\section{Concluding Thoughts - Instead of Conclusion}

No matter how the discourse on conformity, non-conformity, autonomy and authenticity develop, all of us can agree that an indispensable requirement for autonomy is free thought. Intentions, competency and skills in that matter are beautiful ideals, however, at the same time, one of the certain ways to react negatively (if not the most certain) is clamping down on conformity and nonconformity. It should be clearly seen that this problem will persist for a long time in practice. On the one hand, because the misbeliefs and myths in connection with conformism and non-conformism have deeply infiltrated our consciousness. On the other hand, finding solutions for this long-term project requires a lot of energy and firm moral commitment. And it is not even sure that we are ready for that. I can only answer the question (Must you conform?) posed by the American author, Lindner (1956), chosen as a motto for this article in the following manner: one should not necessarily identify oneself with conformism, when it is desirable to reject non-conformist behaviour. One should look for the solution elsewhere, beyond the accepted definitions!

\section{References - with some additional comments [in square brackets] by the author}

Ackerman, N. (1969). The Psychodynamics of Family Life. New York: Bases Blodis.

Asch, S. E. (1951). Effects of Group Pressure upon the Modification and Distortion of Judgments. In Guetzkow, H. (Eds.). Groups, Leadership and Men: Research in Human Relations. United States: Carnegie Press, pp. 177-190.

Barfuss, Th. (2002). Konformität und bizarres Bewusstsein [Conformity and bizarre Consciousness]. Hamburg: Argument Verlag.

[The Heideggerian effect can clearly be detected here.]

Bass, B. M., \& Berg, I. (Eds.) (1971). Conformity and Deviation. New York: Harper and Brothers Publishers. Preface, unnumbered pages.

[The anthology is the standard work of the literature in the field. William Penn's book in German: Früchte der Einsamkeit (1693-1718), Heidelberg, Karl Winters Universität Buchhandlung. Der Konformist.]

Castoriadis, C. (1994). En mal de culture [Being without Culture]. In Esprit, (205.10), pp. 40-50.

[Conformity is a phenomenon of extreme significance. See, for example Gramsci, A. (1970). Filozófiai írások. [Philosophical Writings] Hungary, Budapest: Kossuth Kiadó.]

Cooley, C. H. (1967). Human Nature and the Social Order. United States, New York: Schocken Books.

[This work of the sociologist author has become a classic nowadays. Crutchfield, R. (1955). Conformity and Character. The American Psychologist, 10 pp. 191-198. Furthermore Ballachey, E. L., Crutchfield, R., \& Krech, D. (1962). Individual in Society. A Textbook of Social Psychology. United States, New York: McGraw - Hill Book Company Inc.]

Csepeli, Gy. (1979). A szociálpszichológia vázlata [The Sketch of Social Psychology]. Hungary, Budapest: Népmúvelési Propaganda Iroda.

Descartes, R. (1992). Értekezés a módszerről. [Discourse on Method] Hungary, Budapest: Matúra Bölcselet, Ikon Kiadó.

[This realisation can be considered as the classical opposition to conformity.]

Deutsch, M., \& Krauss, R. (1965). Theories in Social Psychology. New York: Basic Books.

Dévényi, I. (2020). Miniszterúrnak tisztelettel jelentem... [I Report to Mr. Prime Minister with Respect that...] In Magyar Hang, June. 9.

[The sentence written here appears in many opposition manifestos.]

Dworkin, R. (1993). Szabadság, egyenlőség, közösség (Freedom, equality, community).

Emerson, R. W. (1988). Magabiztosság. [Self-Reliance] Új Symposion [New Symposium]. 
[If I mention this journal, I must raise your attention to another article: Új Symposion [New Symposium]. (1965) - republication: Ex Symposion, (2019): Tomislav Ladan: Konformizmus és non-konformizmus. The author discusses the topic's literary aspect. Last but not least: Emerson, R. W. (1932) Essays. First Sevilis Self-Reliance. United States, Washington: Washington National Home Library Foundation.]

Feuer, L. S. (1969). The Conflict of Generations. United States, New York, United Kingdom, London: Basic Books, Inc. Publishers.

Fischer, E. (1964). A fiatal nemzedék problémái. [Problems of the Young Generation] Hungary, Budapest: Gondolat.

[At first glance, one might think that the most condensed and deepest definition of conformity is articulated here. Furthermore Asch, S. (1956). Studies of Independence and Conformity. In Psychological Monographs (70.9) Washington, United States: American Psychological Association (pp. 1-70). Social psychology vividly and sometimes critically reflected on the results of Asch, for example.]

Heidegger, M. (2010) Being and Time. United States, New York: Sunny Press. [Conformity research makes use of the ideas of the famous existential philosopher.]

Ivanov, V. G. (1980). Kollektivizm ili konformizm. Lenizdat [Collectivism or Conformism].

[A PhD dissertation was written on the given topic.]

Karikó, S. (2017). Hitelesség a nevelésben és a kommunikációban [Autenticity in Education and Communication]. In Dombi A., \& Dombi, M. (eds). Pedagógikum éskommunikáció. Hungary, Szeged: SZTE JGYPK.

[The teacher can also fail if he loses his authenticity.]

Karikó S. (2005). Konformitás és nevelés [Conformity and Education]. Hungary, Budapest: Okker Kiadó. Second Edition: 2008.

[I would define it in the same way as I had done before even today, however, I do not exclude the possibility that the definition will become deeper and finer as a result of the research of others.]

Kiesler, Ch. A., \& Kiesler, S. B. (1969). Conformity. United States: Massachusetts: Addison-Wesley Publishing Company.

[There is no actual difference between the two examined concepts.]

Kim, V. V. (2014). Conformism and Non-Conformism as Mechanism of Production and Reproduction of Fanaticism in Society.In Filosofija (7). Russian, Moscow: Vestnyik Moskovskavo Universiija, pp. 84, 98.

[The Russian researcher tends to interpret conformity as a personality trait.]

Kovács, K. (2014): Integrated Education of Children with Special Educational Needs. In Journal of Humanistic and Social Studies. Vol. 5. Issue 2. pp. 99-111.

Lengyel, L. (2001). Fiatal farkasok iskolái [Schools of Young Wolves]. 168 óra, okt. 11.

[The author - as known - is not a pedagogical researcher, nevertheless it is worthwhile for pedagogical academics to take his idea into consideration.]

Lindner, R. M. (1956). Must you Conform? USA, New York: Rinehart Publishing House.

Lóránd, F. (1999). Az emberi minőség tisztelete a komprehenzív iskolában [Respecting Human Quality in Comprehensive School]. Új Pedagógiai Szemle, (49.1). Hungary, Eger: Eszterházy Károly Egyetem, pp. 3-36.

Lukács Gy. 1976: A társadalmi lét ontológiájáról [Discourse on the Ontology of Social Existence]. Hungary, Budapest: Magvető Kiadó.

[Lukács links the question of conformity to the phenomenon of manipulation (it is worth examining this correlation separately). I would like to highlight that the philosophical inquiries about the topic can be made use of along with the other related social sciences.]

Mehlhorn, G., \& Mehlhorn, H.-G. (2003). Kreativitätspädagogik - Entwicklung eines Konzepts in Theorie und Praxis. [Creativity-pedagogy - Conception of Development in Theory and Practice] 
Bildung und Erziehung. Vol. 56, Issue 1, pp. 23-45. [According to the author, creative desiccation is a characteristic feature of our culture.]

Merton, R. (1959). Social Conformity, Deviation and Opportunity Structures. American Sociological Review (24.2). United States, Thousand Oaks: SAGE Publications, pp. 177-189.

[Furthermore Merton, R. (1967). Social Structure. United States, New York: Free Press.]

Moscovici, S. (2002). Társadalom-lélektan [Social Psychology]. Hungary, Budapest: Osiris Kiadó.

[I must mention that the author wrote this study in 1972.]

Michnik, Adam. 1998. Interview to Hungarian Newspaper, May 30.

Moscovici, S. (2002). Társadalom-lélektan [Social Psychology]. Hungary, Budapest: Osiris Kiadó.

Mucchi Faina, A. (1998). Il conformismo [Conformism], Italy, Bologna: il Mulino.

[This is why the author claims that conformity is a tool to reach our goals and at the same an exploding mine. See 117.]

NAT (2020). [Hungarian National Curriculum]. Magyar Közlöny (17). Hungary, Budapest: Magyar Közlöny Lap- és Könykiadó, pp. 290-447.

[In the document, the discussion of autonomy has been omitted, the deficiency is especially obvious when one is reading the description of civic studies and the aims of the education of ethics.]

Nietzsche, F. (1989). A történelem hasznáról és káráról [On the Use and Abuse of History for Life]. Hungary, Budapest: Akadémiai Kiadó.

[Researchers could pay attention to his remarks.]

Oláh, T. (1978). Társadalomlélektani vizsgálatok a konformizmusról [Social Psychological Investigations on Conformism]. In Élet és Tudomány. Vol. 12, Issue 22.

[Szendi associates the conservative personality with the phenomenon of conformity.]

Papyrina, V. (2012). Conformity and Uniqueness in Consumer Choices. In Journal of Consumer Behavior (11.6).

[The author is the researcher and professor at San Francisco State University, one can consider her study as the contestation of Petrovsky's criticism.]

Perrin, St., \& Spencer, Ch. (1981). Independence of Conformity in the Asch Experiment as a Reflection of Cultural and Situational Factors. In British Journal of Social Psychology (20).

[It is surprising that the research conducted among British university students did not confirm Asch's conformity value.]

Peters, R. (1974). Psychology and Ethical Development. London: Georg Allen and Unwin LTD.

Petőfi, S. (1956). Petőfi Sándor Vegyes múvei [Miscellaneous Anthology of Sándor Petőfi's Literary works of Art]. Hungary, Budapest: Akadémiai Kiadó.

[The poet voiced his bitterness due to his indignation at the results of general elections in Szabadszállás.]

Petrovszkij, A.V.(1973). K pasztrojenyiju szocialno-pszichologicseszkoj teorii kollektiva [Collection of Social Psychological Theories]. In Vaproszi Filoszofii (12).

[In his latest work (Licsnoszty, Gyejátyelnoszty, Kollektiv. Politizdat, Moscow, 1982, 33.), he strengthens his standpoint: the decisive factor is not the influence of the individual but the firm value orientation.]

Peuckert, R. (1975). Konformität [Conformity]. Stuttgart: Ferdinand Enke Verlag.

Popper, P. (1975). Nyilatkozat [Manifesto]. In Lénárd, Ferenced (ed.) Ifjúság és pszichológia [The Youth and Psychology]. Hungary, Budapest: Akadémiai Kiadó.

Radó P. 1. (2017). Az iskola jövője. [The Future of the School] Hungary, Budapest: Noran Libro.

[From the ethical perspective, autonomy means the defence of human integrity.]

Scheff, Th. (1988) Shame and Conformity: The Defence-Emotion System. In American Sociological Review, 53.

Szüdi, J. (2019). Csináljunk rossz iskolát! [Let’s Make Bad School]. Wesley János Hungary, Budapest: Lelkészképző Főiskola. 
[According to the author, the "all for the children" kind of program has been disrupted or it has turned the other way around. His most overwhelming statement is that the workload of children is far more considerable than that of teachers.]

Tamás Gáspár. M. (2020). Torkos Matild interjúja Tamás Gáspár Miklóssal [The Interview of Matild Torkos with Miklós Tamás Gáspar]. In Magyar Hang, Július 24-30.

[In the interview, the author voices - the already known - sharp criticism which can open up a debate, but at least it is worth thinking about it a bit.]

Vekerdy, T. (2019). Engedelmes rabszolgákat nevelünk. (Teczár Szilárd interjúja Vekerdy Tamással) [We are Educating Obeying Slaves (The Interview of Szilárd Teczár with Tamás Vekerdy] Magyar Narancs, XXXI. 30. júl. 25. 8.

[The development of critical reflexivity has been banished from our public educational system.]

Wiswede, G. (1976). Soziologie Konformen Verhaltens. [Sociology of Conformity Behaviour]. Stuttgart: Kohlhammer.

[There are two approaches to conformism: adaptation for the sake of the proper functioning of the system and the negative alignment from a social critical perspective.]

Zajonc, R. (1968). Conformity.In International Encyclopaedia of the Social Science. United States, New York: The Macmillan Company and The Free Press.

Remark of the author: The unpublished version of this study was written in Hungarian. It was translated to English by Erik István Papp, philologist in English studies.

\section{About the Author}

Prof. em. Dr. Sándor Karikó: Emeritus, Professor, Philosophy of Education, Faculty of Humanities and Social Sciences, University of Szeged (Hungary); e-mail: bacon@jgypk.u-szeged.hu 